\title{
TINJAUAN YURIDIS TERJADINYA DELIK PENADAHAN DI WILAYAH HUKUM POLRES LUWU
}

\author{
Andi Takdir Djufri \\ Universitas Andi Djemma Palopo \\ Email: takdirjufri@gmail.com
}

\begin{abstract}
This research is conducted precisely in the jurisdiction of Polres Luwu by using primary data obtained from direct interviews or observation and secondary data obtained from the results of literature review, in the form of books, report materials, articles and other documents. Data were analyzed using qualitative analysis technique then processed systematically.

The factors causing the occurrence of a criminal offense in the jurisdiction of Luwu Police from 2015 to 2017 are the ignorance of the perpetrators of the origin of the goods obtained, limited employment, and low education. Efforts that have been made by the police in tackling the criminal offense that occurred in the Luwu Police Precinct is with efforts that are preventive and repressive
\end{abstract}

Keywords: Decalification

\begin{abstract}
Abstrak
Penelitian ini dilaksanakan tepatnya di wilayah hukum Polres Luwu dengan menggunakan data primer yang diperoleh dari hasil wawancara langsung atau observasi dan data sekunder yang diperoleh dari hasil kajian pustaka, berupa buku, bahan laporan, artikel dan dokumen lainnya. Data dianalisa dengan menggunakan teknik analisa kualitatif kemudian diolah secara sistematis.

Faktor yang menyebabkan terjadinya delik penadahan di wilayah hukum Polres Luwu dari tahun 2015 sampai dengan tahun 2017 adalah ketidaktahuan pelaku tentang asal-usul barang yang diperoleh, lapangan kerja yang terbatas, dan pendidikan yang rendah. Upaya yang telah dilakukan pihak kepolisian dalam menanggulangi delik penadahan yang terjadi di wilayah hukum Polres Luwu adalah dengan upaya yang bersifat preventif dan represif
\end{abstract}

Kata kunci : Penadahan

Jurisprudentie | Volume 4 Nomor 2 Desember 2017 


\section{LATAR BELAKANG}

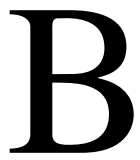
erkembangnya dunia yang sangat cepat saat ini maka salah satu yang menjadi pilar utama dalam menciptakan ketentraman dan kedamaian adalah adanya aturan hukum yang menjadi pedoman dan patokan yang harus ditaati oleh setiap manusia. Hukum adalah rangkaian peraturan-peraturan mengenai tingkah laku manusia sebagai suatu anggota masyarakat, sedangkan tujuan dari hukum antara lain mengadakan keselamatan, kemanfaatan, keadilan dan keterampilan dalam masyarakat.

Pada dasarnya Hukum diartikan sebagai suatu sistem mendidik, mengajak dan memaksa warga masyarakat agar berperilaku sesuai dengan hukum. Dengan kata lain dari sudut sifatnya dapat dikatakan bahwa pengendalian sosial dapat bersifat preventif maupun represip. Preventif merupakan suatu cara dalam hal untuk mencegah terjadinya perilaku yang tidak dikendaki oleh berbagai aturan yang dapat menyimpang, sedangkan tindakan represif adalah bertujuan untuk mengembalikan keserasian.

Dalam perkembangan dimana penduduk semakin bertambah, sehingga kondisi pertambahan penduduk tersebut sangat berpengaruh terhadap kondisi lingkungan khususnya ekonomi masyarakat, terutama menyangkut masalah pemenuhan kebutuhan sehari-hari. Hal ini mudah sekali menimbulkan kerawanan di bidang keamanan masyarakat yaitu seringnya terjadi suatu kejahatan

Sehingga dengan demikian terjadinya tindak pidana adalah suatu perilaku menyimpang dan bertentangan dengan aturan maupun hukum itu sendiri dalam kehidupan masyarakat. Perilaku menyimpang itu merupakan ancaman yang selalu terjadi dan bahkan setiap saat memungkinkan untuk terjadi pada setiap orang.

Delik penadahan yang selalu terjadi sebagaimana yang telah ditetapkan dan diatur dalam buku II khususnya pada Bab XXX KUHP, yaitu mulai pasal 480 sampai dengan pasal 484 Kitab Undang-Undang Hukum Pidana ( KUHP) dengan demikian dapat dikemukakan beberapa rumusan tentang tentang kejahaan penadahan sebagai berikut :

Dalam rumusan tersebut yang berbunyi bahwa dapat dipidana penjara selama-lamanya empat tahun atau denda sebanyak-banyaknya sembilan ratus rupiah. yaitu :

Dengan demikian mengingat karena bersalah menadah, barang siapa membeli, menyewa, menukar, menerima gadai, menerima sebagai hadiah atau karena mau mendapat untung, menjual, menyewa, menukarkan, menggadaikan , membawa menyimpan atau menyembunyikan sesuatu barang yang diketahuinya atau patut disangka, bahwa barang itu diperoleh dari hasil kejahatan. 
Berbagai dasar yang lain bahwa barang siapa mengambil untung dari sesuatu barang yang diketahuinya atau patut dapat disangkanya bahwa barangbarang itu diperoleh karena kejahatan.

\section{METODE PENELITIAN}

Penelitian ini dilaksanakan tepatnya di wilayah hukum Polres Luwu dengan alasan bahwa di wilayah tersebut masih banyak terjadi penadahan barang-barang yang diperoleh dengan tidak sah. Jenis dan sumber data yang digunakan yaitu data primer yang diperoleh dari hasil wawancara langsung di lokasi penelitian dalam hal ini berupa data yang terhimpun dari keterangan pelaku dan data sekunder yang diperoleh dari hasil kajian pustaka, berupa buku, bahan laporan, artikel dan dokumen lainnya.

Teknik pengumpulan data yang digunakan dalam penelitian ini adalah observasi yaitu dilakukan dengan jalan mengadakan pengamatan secara langsung pada fokus kejadian dalam penelitian ini dan wawancara yang dilakukan dengan mengadakan wawancara dengan responden, berdialog dengan responden terutama untuk memperoleh data primer. Data dianalisa dengan menggunakan teknik analisa kualitatif kemudian diolah secara sistematis.

\section{HASIL PENELITIAN DAN PEMBAHASAN}

\section{A. Faktor Penyebab Terjadinya Delik Penadahan di Wilayah Hukum Polres Luwu}

Berbicara tentang penadahan, maka banyak faktor penyebab terjadinya kejahatan termasuk kejahatan dalam bentuk penadahan yang dilakukan oleh masyarakat dewasa ini, terutama masyarakat yang tidak mempunyai pekerjaan tetap, maka Hal-hal yang menyebabkan terjadinya delik penadahan baik dikota maupun didaerah disebabkan berbagai penyebab, dengan kondisi saat ini sebagaimana diketahui bahwa delik penadahan merupakan masalah aktual yang setiap saat menjadi pembicaraan dimana-mana termasuk faktor penyebabnya sangat beraneka ragam. Hal tersebut merupakan suatu fenomena sosial yang dihadapi masyarakat, baik yang ada diperkotaan maupun yang ada di daerah pedesaan, sebagaimana halnya selama ini banyak di jumpai termasuk wilayah hukum Polres Luwu .

Dari beberapa hasil penelitian serta wawancara penulis bahwa ada beberapa faktor penyebab terjadinya kejahatan di wilayah hukum Polres Luwu yang dijumpai selama ini adalah : 
1. Ketidaktahuan pelaku tentang asal-usul barang.

2. Ekonomi yang terhempit

3. Lapangan pekerjaan yang terbatas

4. Pendidikan yang rendah

Dari berbagai faktor yang lain Keempat faktor penyebab terjadinya delik penadahan di wilayah hukum tersebut, sebagaimana dikemukakan responden, dan menurut pendapat penulis sendiri masih kurang dipahami, oleh karena itu perlu diteliti dan di kaji lebih lanjut dengan mengadakan pendekatan dari segi kriminologi sehingga jelas batas serta ruang lingkup dikatakan suatu penadahan.

a. Ketidaktahuan tentang barang yang diperoleh.

Ketidak tahuan juga merupakan suatu hal yang harus diperhatikan apakah memang tidak tahu atau sengaja tidak tahu sehingga para pihak mengatakan bahwa para pelaku penadahan tidak mengetahui bahwa barang yang dibelinya adalah barang hasil perbuatan kejahatan, tetapi menurut pendapat penulis bahwa ada pelaku penadahan yang memang benar-benar suka menadah barang - barang hasil perbuatan kejahatan padahal mereka tahu bahwa dengan membeli barang tersebut merupakan suatu pelanggaran. Seseorang melakukan penadahan disebabkan karena barang yang ia beli dengan harga murah kemudian mereka jualnya lagi dengan harga tinggi.

b. Tingkat konomi yang rendah

Keadaan yang digambarkan tersebut dapat dimengerti proses-proses sosial ekonomi yang dialami warga masyarakat. Meliputi pula dinamika sosial yang melatar belakangi perbuatan - perbuatan jahat. Pada golongan masyarakat tertentu. Khususnya lapisan masyarakat yang berstatus sosial - ekonomi rendah yang kini merupakan mayoritas penghuni lembaga - lembaga pemasyarakatan. Kejahatan tidak terlepas dari kondisi sosial ekonomi yang tengah berlangsung dan mengakomodasi bentuk- bentuk sikap perilaku para warga masyarakat yang bersangkutan. identik hal tersebut, diungkapkan dari Salah seorang pembina warga binaan pada lembaga pemasyarakatan pada (wawancara tanggal 20 Nopember 2017 ( dalam keterangannya bahwa, pada umumnya warga binaan yang ada di lembaga pemasyarakatan ini adalah yang mempunyai kondisi sosial ekonomi yang sangat lemah, karena tidak mempunyai pekerjaan atau tidak mempunyai pekerjaan tertentu yang dapat dinikmati para keluarga setiap saat sehingga dengan demikian cara hal seperti itu yang banyak 
dilakukan untuk memenuhi kehidupan sehari-hari. Dalam pembicaraan mengenai ekonomi dengan masalah delik penadahan, kiranya menarik untuk diperhatikan pandangan kriminologi bahwa, saat ini kondisi sosial ekonomi memang mempunyai pengaruh terhadap terjadinya atau timbulnya kejahatan. Namun harus diperhatikan bahwa kondisi sosial ekonomi itu hanya merupakan sebagian dari sejumlah faktorfaktor lain yang memberi perangsang dan dorongan ke arah kriminalitas. Berdasarkan pandangan ahli kriminologi tersebut maka dapatlah ditarik kesimpulan bahwa, akibat tekanan ekonomi yang dihadapi oleh seseorang akan memaksa mereka untuk mencari pekerjaan untuk memenuhi kebutuhan hidupnya, walaupun pekerjaan yang dilakukan itu bertentangan dengan Undang-Undang, akan tetapi apakah dengan mengakui dan menyadari hal itu akan membuat mereka untuk bisa hidup lebih baik. Inilah tantangan yang dihadapi oleh pelaku delik penadahan tersebut, dalam hal ini delik penadahan yang terjadi di wilayah tersebut.

c. Lapangan pekerjaan yang sangat terbatas

d. Pendidikan yang sangat rendah

Pendidikan tidak dapat disangkal bahwa peranan pendidikan sangat besar pengaruhnya terhadap pembentukan watak pribadi seseorang. Individu yang berpendidikan kemungkinan lebih tabah dalam menghadapi problema sosial di sekitarnya. Sebaliknya individu yang tidak atau kurang berpendidikan sangat potensial berpengaruh oleh kondisi sosial dimana dia berada. Hal ini kemungkinan disebabkan mencari nafkah, kemudian ditambah kurang berfikir kritis dalam menyikapi kondisi sekitarnya.

Beberapa pandangan ahli kriminologi bahwa kejahatan dapat pula merupakan akibat daripada kurangnya pendidikan sama halnya dengan kegagalan yang disebabkan oleh kondisi lingkungan keluarga.

\section{B. Penegakan Hukum dalam menekan delik penadahan di wilayah hukum Polres Luwu}

Banyaknya pelanggaran serta terjadinya berbagai macam delik yang terjadi dipermukaan, tentunya para penegak hukum akan berupaya semaksimal mungkin dalam memberantas serta mengantisipasi terjadinya delik yang tidak diharapkan. Mengenai upaya yang terus menerus dilakukan oleh aparat kepolisian khususnya kepolisian dalam mengantisipasi berbagai kejahatan yang bisa muncul utamanya delik penadahan yang banyak terjadi sehingga dengan demikian 
menurut pandangan kriminologi bahwa, kejahatan selalu ada karena kejahatan dalam masyarakat tidak dapat dihilangkan akan tetapi kejahatan dalam masyarakat harus dikurangi baik yang dilakukan oleh seluruh lapisan masyarakat ataupun struktur hukum itu sendiri.

Namun demikian banyaknya kejahatan di dunia tidak dapat dihapuskan sekaligus, namun manusia hanya dapat berusaha untuk memperkecil atau mengurangi kejahatan sebagai penyakit dalam masyarakat. Kejahatan dalam masyarakat sama halnya dengan pergantian musim yang tidak dapat dihindari oleh manusia sebagai keadaan alamiah.

Berbagai pendapat tersebut dapat disimpulkan bahwa kejahatan tidak mungkin bisa lenyap dimuka bumi ini, sepanjang dunia masih dihuni oleh makluk sosial. Demikian halnya berbagai upaya yang telah dilakukan dalam menanggulangi serta menekan jumlah terjadinya kejahatan yaitu dengan cara upaya preventif serta upaya refresif.

\section{Upaya preventif}

Upaya preventif adalah tindakan yang dilakukan secara preventif dapat dibedakan sebagai berikut:

a) mengadakan sistem keamanan lingkungan, penanggulangan ini diawali dengan menciptakan dan membina sistem lingkungan yang dapat mengurangi tahap-tahap kejahatan dari orang-orang yang telah siap atau potensial melakukan kejahatan dari orangorang yang telah siap atau potensial melakukan kejahatan dengan mendayagunakan segenap potensi masyarakat sebagai aplikasi perwujudan tanggung jawab bersama dalam pembinaan kabtibmas dengan mengaktifkan fungsi-fungsi yang telah terorganisasi seperti hansip.

b) Meningkatkan pengamanan terhadap daerah yang dianggap rawan terjadinya kejahatan, seperti di pasar dan tempat yang dianggap sebagai tempat terjadinya barang hasil curian.

c) Mengadakan penyuluhan dalam lingkungan masyarakat yakni berupa:

1. Penyuluhan hukum

penyuluhan hukum ini terutama ditujukan kepada orangorang yang mempunyai tingkat pendidikan rendah, dalam arti bahwa yang masih kurang mengerti tentang hukum. Hal ini dilakukan dengan bekerja sama pihak yang berkecimpung dalam disiplin ilmu hukum agar dapat 
menyadari atau mengetahui mengenai hakekat hukum yang sebenarnya.

2. Penyuluhan Agama

peranan imam dapat menangkang kejahatan. Sertiap orang yang melakukan kejahatan berarti mengalami krisis iman, sebab manakala orang tersebut dalam keadaan beriman atau menyadari kejahatan itu dilarang oleh agama dan berakibat mendapat siksa di akhirat, ia tidak akan melakukan kejahatan tersebut.

2. Pembinaan di dalam Lembaga Pemasyarakatan

Di dalam pembinaan ini para narapidana harus diakui sebagai makhluk sosial, karena kita ketahui bahwa tujuan dari pemidanaan adalah untuk membuat jera kepada pelaku penadahan serta memberikan pembinaan ini harus berdasarkan sosial, yakni menempatkan narapidana ditengah-tengah terpidana lainnya seperti pembinaan meliputi :

a) Pembinaan mental

pembinaan mental ini bertujuan agar supaya narapidana tidak mengalami frustrasi, putus asa, perasaan rendah diri terus menerus dan lain sebagainya.

b) Pembinaan sosial

Pembinaan ini bertujuan agar terpidana dapat kembali hidup ditengah-tengah masyarakat tanpa mengganggu kehidupan masyarakat.

c) Pembinaan keterampilan, dalam pembinaan keterampilan ini dimaksudkan untuk memupuk dan mengembangkan bakat yang dimiliki, sehingga ia dapat memperoleh keahlian sesuai dengan kebutuhan lingkungannya, seperti pelajaran menjahit, membuat kue dan lain sebagainya yang bermanfaat bagi masa depan terpidana jika kelak sudah habis masa waktu tahanan yang ditempuh.

3. Pembinaan di Luar Lembaga

Pembinaan ini dilakukan diluar dari lokasi lembaga pemasyarakatan atau pembinaan yang dilakukan ditengah-tengah masyarakat dan instansi pelaksanaannya adalah bimbingan kemasyarakatan. Jadi, pada prinsipnya lembaga pemasyarakatan itu adalah 
merupakan 'Pengayoman" yang berarti, bahwa masyarakat telah diayomi terhadap diulanginya perbuatan oleh terpidana.

Adanya usaha-usaha penaggulangan atau pembinaan dan pendidikan yang serius, terarah dan terus menerus, pada suatu saat dapat menggugah masyarakat untuk meninggalkan perbuatan kejahatan, dengan demikian diharapkan masyarakat akan meningkat kesadaran hukumnya.

Sebagaimana hasil wawancara penulis yang menyatakan bahwa delik penadahan yang terjadi di wilayah hukum Polres Luwu karena dipengaruhi adanya beberapa faktor antara lain :

a. Kurangnya kesadaran hukum masyarakat untuk mematuhi segala peraturan serta kurangnya perhatian masyarakat, untuk melaporkan bila ada terjadi kejahatan tersebut;

b. Tidak adanya saksi yang tegas

c. Terbatasnya petugas kepolisian bila dibandingkan dengan jumlah kejahatan yang terjadi.

Dilihat dari segi usia pelaku yang melakukan delik penadahan di wilayah hukum Polres Luwu dapat tergambar dalam tabel sebagai berikut :

Tabel 1

Usia Pelaku Penadahan di wilayah hukum Polres Luwu 2015 - 2017

\begin{tabular}{|c|c|c|c|c|}
\hline \multirow{2}{*}{ Umur Pelaku } & \multicolumn{3}{|c|}{ Tahun } & \multirow{2}{*}{ Jumlah } \\
\cline { 2 - 5 } & 2015 & 2016 & 2017 & \\
\hline 17-25 tahun & 1 & 3 & 0 & 4 \\
26-34 tahun & 4 & 7 & 1 & 12 \\
$35-43$ tahun & 2 & 5 & 2 & 9 \\
$44-52$ tahun & 4 & 1 & 2 & 7 \\
\hline Jumlah & 11 & 16 & 5 & 32 \\
\hline
\end{tabular}

Sumber Data : Data primer diolah 2017

Memperhatikan tabel dua di atas, tampak bahwa yang paling banyak yang melakukan delik penadahan di wilayah hukum dalam jangka waktu tahun 2015 
sampai dengan tahun 2017 adalah pelaku yang berumur 26-34 tahun yaitu sebanyak 12 pelaku, sedangkan yang berumur 35-43 tahun sebanyak 9 orang pelaku penadahan barang.

Tampak tersebut diatas nampak bahwa usia pelaku yang melakukan delik penadahan diwilayah hukum adalah pada umumnya adalah usia yang masih produktif. Sehingga terjadinya kejahatan seperti tersebut diatas disebabkan karena ingin menjadi sebagai suatu pekerjaan mereka, karena sebenarnya masih banyak pekerjaan yang mesti mereka kerjakan karena dia masih kuat untuk bekerja, namun karena ingin yang gampang saja akahirnya akan melakukan suatu pekerjaan tersebut.

Sesuai hasil penelitian yang diperoleh penulis, bahwa pelaku delik penadahan yang terjadi di wilayah hukum Polres Luwu, adalah semuanya dilakukan oleh seorang laki-laki, dan tidak seorang pun perempuan sebagai pelakunya. Untuk lebih jelasnya dapat dilihat pada tabel sebagai berikut :

Tabel 3

Jenis Kelamin Pelaku Penadahan di wilayah hukum Polres Luwu tahun 2015-2017

\begin{tabular}{|c|c|c|c|c|}
\hline \multirow[t]{2}{*}{ Jenis kelamin Pelaku } & \multicolumn{3}{|c|}{ Tahun } & Jumlah \\
\hline & 2015 & 2016 & 2017 & \\
\hline Laki-laki & 2 & 1 & 8 & \\
\hline Perempuan & - & - & - & \\
\hline Jumlah & 11 & 16 & 5 & 32 \\
\hline
\end{tabular}

Sumber Data : Data primer diolah 2017

Berdasarkan tabel tiga tersebut, terlihat dengan jelas bahwa selama dalam jangka waktu tahun 2015 sampai dengan tahun 2017, tidak pernah tejadi delik penadahan di wilayah hukum Polres Luwu yang pelakunya seorang perempuan. Jadi, diantara 32 jumlah keseluruhan pelaku pada lima tahun terkahir tersebut, pelakunya adalah laki-laki pada umumnya. Jadi dengan memperhatikan tabel diatas, maka pekerjaan yang dilakukan oleh pelaku adalah suatu pekerjaan yang rutin yang diharapkan suatu pekerjaan utama yang diharapkan mendapatkan hasil yang ingin dicapai dalam hidupnya.

Demikian pula tentang pekerjaan pelaku yang melakukan penadahan sebagai pekerjaan mereka, jadi pada hakekatnya keadaan status pekerjaan/profesi seseorang dapat pula mempengaruhi meningkatnya angka delik penadahan, seperti yang terjadi di wilayah hukum Polres Luwu. 
Sesuai data yang diproses di wilayah hukum Polres Luwu, maka dapat diketahui pekerjaan pelaku delik penadahan. Untuk lebih jelasnya, dapat dilihat pada tabel di bawah ini :

Tabel 4

Pekerjaan Pelaku Delik Penadahan di wilayah hukum PolresLuwu 2015 - 2017

\begin{tabular}{|c|c|c|c|c|}
\hline \multirow{2}{*}{$\begin{array}{c}\text { Status Pekerjaan } \\
\text { Pelaku }\end{array}$} & \multicolumn{3}{|c|}{ Tahun } & Jumlah \\
\cline { 2 - 5 } & 2015 & 2016 & 2017 & \\
\hline Pengangguran & 7 & 9 & 2 & \\
Tukang Becak & 1 & 2 & 1 & \\
Buruh Bangunan & 3 & 5 & 2 & \\
\hline Jumlah & 11 & 16 & 5 & 32 \\
\hline
\end{tabular}

Sumber data : data primer diolah 2017

Tabel empat tersebut, tampak dengan jelas bahwa diantara 32 orang pelaku yang melakukan delik penadahan di wilayah hukum Polres Luwu dalam jangka waktu tahun 2015 sampai dengan tahun 2017, dilihat dari pekerjaan mereka relatif rendah. Jumlah yang tertinggi pelaku yang melakukan delik penadahan yakni ada 18 orang pelaku yang tidak mempunyai pekerjaa/pengangguran, kemudian 4 orang pelaku pekerjaannya sebagai tukang becak dan yang mempunyai pekerjaan sebagai buruh bangunan tercatat ada 10 orang.

Jadi, disini status pekerjaan pelaku di wilayah hukum Polres Luwu , juga mempunyai pengaruh terjadinya Delik Penadahan. Dengan demikian faktor ekonomi tidak lepas dari penyebab terjadinya kejahatan khususnya delik penadahan itu sendiri. Karena dengan suatu profesi yang tidak menentu rasanya agak susah untuk menutupi kebutuhan sehari-hari. Apalagi jika mereka (pelaku) telah berkeluarga dan mempunyai beberapa orang anak, dan tidak mentup kemungkinan timbulnya tekanan akan selalu ada. Karena dorongan dari akibat tekanan yang dihadapi mereka, memaksa untuk pekerjaan atau sumber lain untuk memenuhi kebutuhannya, walaupun dengan cara yang demikian tidak dapat dibenarkan atau bertentangan dengan kaidah hukum yang berlaku.

Demikian pula akan diuraikan penulis tentang tingkat pendidikan para pelaku penadahan yang sering terjdi di wilayah hukum dengan demikian Tingkat pendidikan seseorang sangat mempengaruhi keadaan jiwa, tingkah laku terutama intelegensinya dalam melakukan suatu kejahatan. Karena pada umumnya seseorang yang melakukan kejahatan dalam masyarakat adalah seseorang yang tidak memiliki pendidikan baik pendidikan formal ataupun non formal. 
Berdasarkan data yang diperoleh penulis dalam penelitian menunjukkan bahwa, semakin rendah tingkat pendidikan seseorang semakin banyak pula melakukan kejahatan. Hal ini, dapat dilihat pada tabel sebagai berikut :

Tabel 5

Tingkat Pendidikan Penadahan di wilayah hukum

Polres Luwu 2015-2017

\begin{tabular}{|c|c|c|c|c|}
\hline Tingkat Pendidikan & \multicolumn{3}{|c|}{ Tahun } & Jumlah \\
\cline { 2 - 4 } & 2005 & 2006 & 2007 & \\
\hline Buta Huruf & 5 & 7 & 2 & 14 \\
Sekolah Dasar & 3 & 4 & 1 & 8 \\
SLTP & 2 & 3 & 1 & 6 \\
SLTA & 1 & 2 & 1 & 4 \\
Perguruan Tinggi & - & - & - & - \\
\hline Jumlah & 11 & 16 & 5 & 32 \\
\hline
\end{tabular}

Sumber Data : data primer diolah 2017

Dengan memperhatikan tabel lima tersebut, tergambar pelaku delik penadahan di wilayah hukum Polres Luwu dalam jangka waktu tahun 2015 sampai dengan tahun 2017, yang paling banyak adalah mereka berpendidikan tingkat SD yaitu sebanyak 8 orang, kemudian menyusul yang SLTA yakni sebanyak 4 orang, selanjutnya yang buta huruf tercatat 14 orang, yang berpendidikan SLTP terdapat 6 orang, dan berpendidikan Perguruan Tinggi tidak pernah ada pelaku.

Data tersebut, bahwa di wilayah hukum Polres Luwu memperlihatkan indikasi bahwa, semakin tinggi tingkat pendidikan, semakin cenderung menurun tingkat delik penadahan. Bagitupula sebaliknya, bahwa semakin rendah tingkat pendidikan semakin cenderung meningkat tingkat delik penadahan.

Dengan tingkat pendidikan mempunyai pengaruh yang tidak kecil terhadap masalah kriminalitas, Namun hal ini tidak bersifat mutlak, sebab faktorfaktor lain yang tidak dapat diabaikan peranannya. Akan tetapi data yang diuraikan di atas, telah menunjang pembuktian bahwa tidak seorang pelaku delik penadahan yang berpendidikan tingkat perguruan tingkat tinggi selama kurun waktu tersebut.

Mengenai status kawin pelaku yang penulis peroleh selama penelitian dapat diketahui bahwa para pelaku delik penadahan di wilayah hukum Polres Luwu dalam jangka waktu tahun 2015 sampai dengan tahun 2017, adalah yang 
berstatus sudah kawin. Untuk lebih jelasnnya, dipaparkan dalam bentuk tabel sebagai berikut :

Tabel 6

status pelaku Delik Penadahan di wilayah Hukum

2015-2017

\begin{tabular}{|c|c|c|c|c|}
\hline Status Kawin Pelaku & \multicolumn{3}{|c|}{ Tahun } & Jumlah \\
\cline { 2 - 4 } & 2015 & 2016 & 2017 & \\
\hline Belum Kawin & 8 & 12 & 3 & 23 \\
Sudah Kawin & 3 & 4 & 2 & 9 \\
& & & & \\
\hline Jumlah & 11 & 16 & 5 & 32 \\
\hline
\end{tabular}

Sumber Data : ,data primer diolah 2017

Dengan melihat data tersebut, bahwa pelaku yang paling banyak melakukan delik penadahan di wilayah hukum Polres Luwu adalah pelakunya yang berstatus kawin yakni sebanyak 23 orang diantara 32 orang pelaku tersebut, sedangkan yang berstatus belum kawin hanya 9 orang pelaku.

Uraian di atas pada umumnya pelaku yang melakukan delik penadahan di proses adalah kondisi sosial ekonomi yang sangat rendah. Tingginya frekuensi delik penadahan khususnya yang terjadi di wilayah hukum Polrse Luwu yang berstatus kawin, mudah dimengerti apabila dihubungkan dengan pembahasan mengenai uraian data umur pelaku serta kondisi sosial ekonomi pelaku menurut aparat Kepolisian, bahwa pelaku penadahan yang terbanyak adalah mereka (lakilaki) yang berumur antara 26-34 tahun, maka logis sekali apabila pada umur demikian kebanyakan mereka sudah kawin bahkan kemungkinan besar sudah mempunyai beberapa anak/keturunan hal ini, tentu mempunyai atau memikul tanggung jawab dan beban kehidupan yang lebih besar pula dibanding orang yang tidak atau belum kawin. Apalagi diketahui bahwa, pada umumnya pelaku kejahatan tersebut mempunyai tingkat pendidikan sangat minim, maka dapatlah dibayangkan betapa sulitnya mendapatkan suatu pekerjaan akhirnya, ditempuh cara-cara pemecahan yang justru langsung atau tidak langsung mengarah pada timbulnya suatu kejahatan termasuk delik penadahan. 


\section{PENUTUP}

Berdasarkan uraian pembahasan dalam skripsi ini maka penulis menyimpulkan sebagai berikut:

1. Bahwa faktor yang menyebabkan terjadinya delik penadahan di wilayah hukum Polres Luwu dari tahun 2015 sampai dengan tahun 2017, adalah :

a. Ketidaktahuan pelaku tentang asal-usul barang yang diperoleh;

b. Lapangan kerja yang terbatas; dan

c. Pendidikan yang rendah

2. Upaya yang telah dilakukan pihak kepolisian dalam menanggulangi delik penadahan yang terjadi di wilayah hukum Polres Luwu adalah :

a. Upaya yang bersifat Preventif :

1) Mengadakan sistem keamanan lingkungan.

2) Meningkatkan penanganan terhadap daerah yang dianggap rawan terjadinya kejahatan dalam hal ini kejahatan delik penadahan.

3) Penyuluhan agama, dan penyuluhan hukum.

b. Upaya yang bersifat Represif :

1) Melakukan penangkapan dan pemahaman

2) Melakukan razia yang dilakukan secara terpadu

3) Melakukan pembinaan para pelaku kejahatan tersebut 


\section{DAFTAR PUSTAKA}

Abdulsyani, 1987, Sosiologi Kriminilitas, Remadja karya, Bandung

Arif Gosita, 1985, Masalah Korban Kejahatan, Akademika Presindo, Jakarta.

Andi Zainal Abidin Farid, 1981, Bunga Rampai Hukum Pidana, Akademika Presindo, Jakarta.

Bonger. W.A. 1982, Masalah Kejahatan Dengan Sebab Akibat, Pradnya Paramita, Jakarta.

Edi Setiadi, 1999. Hukum Pidana dan Perkembangannya. Fakultas Hukum UNISBA, Bandung.

Hilman Hadikusuma, 1984. Bahasa Hukum Indonesia. Alumni, Bandung.

Hari Saherodji, 1980, Pokok-pokok Kriminologi, Aksara Baru, jakarta.

Ilham Gunawan. 2002. Kamus Hukum. Restu Agung, Jakarta.

Lamintang, P.A.F. 1984, Dasar-dasar Hukum Pidana, Aksara Baru, Jakarta

Moeljatno, 1983, Kriminologi, Bina Aksara, Jakarta. , 1986, Azas-azas Hukum Pidana, Bumi Aksara, Jakarta.

Mulyana W. Kusumah, 1981, Kriminologi dan Masalah Kejahatan, Armico. Bandung. , 1982, Aneka Permasalahan, Dalam ruang Lingkup Kriminologi. Alumni, Bandung. , 1983, Kejahatan Penjahat dan Reaksi Sosial. Penerbit Alumni, Bandung.

Rusli Effendy, 1980, Azas-azas Hukum Pidana Bagian I. Lembaga Kriminologi Unhas, Ujung Pandang. 1986, Manusia dan Kejahatan, Lembaga Kriminologi, Unhas, Ujung Pandang.

Soedjono Dirjosisworo, 1983, Penanggulangan Kejahatan, Alumni, Bandung.

Soerjono Soekanto, 1981, Kriminologi Suatu Pengantar, Ghalia Indonesia, Jakarta. , 1986, Pengantar Penelitian Hukum, UI-PRESS, Jakarta.

Topo Santoso, Eva Achanizulfa. 2003, Kriminologi. PT. Raja Grafindo Persada. Jakarta.

Wirjono Prodjodikoro, 1980, Tindak-tindak Pidana Khusus. Usaha Nasional. Surabaya 